\title{
Light Soaking Induced Increase in Conversion Efficiency in Solar Cells Based on $\operatorname{In}(\mathrm{OH})_{x} \mathrm{~S}_{y} / \mathrm{Pb}(\mathrm{OH})_{x} \mathrm{~S}_{y}$
}

\author{
Robinson Musembi ${ }^{1 *}$, Bernard Aduda ${ }^{1}$, Julius Mwabora ${ }^{1}$, Marin Rusu ${ }^{2}$, Kostantinos Fostiropoulos ${ }^{2}$, \\ Martha Lux-Steiner ${ }^{2}$ \\ ${ }^{1}$ Department of Physics, School of Physical Sciences, University of Nairobi, Nairobi, Kenya; ${ }^{2}$ Solarenergieforsung (SE2), Lise- \\ Meitner Campus, Hermholtz-Zentrum Berlin für Materialien und Energie, Berlin, Germany. \\ Email: *musembirj@uonbi.ac.ke
}

Received August 25 $5^{\text {th }}, 2012$; revised October $18^{\text {th }}, 2013$; accepted November $2^{\text {nd }}, 2013$

Copyright (C) 2013 Robinson Musembi et al. This is an open access article distributed under the Creative Commons Attribution License, which permits unrestricted use, distribution, and reproduction in any medium, provided the original work is properly cited.

\begin{abstract}
Light soaking characterization on complete $\mathrm{SnO}_{2}: \mathrm{F} / \mathrm{TiO}_{2} / \mathrm{In}(\mathrm{OH})_{x} \mathrm{~S}_{y} / \mathrm{Pb}(\mathrm{OH})_{x} \mathrm{~S}_{y} / \mathrm{PEDOT}$ :PSS/Au, eta solar cell structure as well as on devices which do not include one or both $\mathrm{TiO}_{2}$ and/or PEDOT:PSS layers has been conducted. Additionally, studies of $\mathrm{SnO}_{2}: \mathrm{F} / \mathrm{In}(\mathrm{OH})_{x} \mathrm{~S}_{y} / \mathrm{Pb}(\mathrm{OH})_{x} \mathrm{~S}_{y} / \mathrm{PEDOT}: \mathrm{PSS} / \mathrm{Au}$ solar cell have been performed. The power conversion efficiency and the short circuit current density have been found to increase with light soaking duration by a factor of about $1.6-2.7$ and $2.1-3$, respectively. The increase in these two parameters has been attributed to the filling up of trap states and/or charge-discharge of deep levels found in $\operatorname{In}(\mathrm{OH})_{x} \mathrm{~S}_{y}$. These effects take place at almost fill factor and open circuit voltage being unaffected by the light soaking effects.
\end{abstract}

Keywords: Eta Solar Cell; Light Soaking; Conversion Efficiency; $\mathrm{TiO}_{2} ; \mathrm{In}(\mathrm{OH})_{x} \mathrm{~S}_{y} ; \mathrm{Pb}(\mathrm{OH})_{x} \mathrm{~S}_{y}$

\section{Introduction}

Extremely thin absorber (eta) solar cell is a photovoltaic device proposed a few years ago $[1,2]$ and is modeled on dye sensitized solar cell concept $[3,4]$. Unlike its dye sensitized solar cell counterpart where light absorption occurs in a monolayer of organic/or metalorganic dye molecule, in eta solar cell, the dye is replaced with a solid state inorganic sensitizer which is sandwiched between two wide band gap semiconductor materials, one n-type and the other one p-type. The photovoltaic effect of this type of device is due to charge carrier injection from the sensitizer material.

Since the eta concept inception, the conversion efficiency of this type of device has remained very low. A number of techniques have been proposed over the years towards improvement of the solar cell characteristics of this type of device. Some of the methods which have successfully been used so far include: insertion of a very thin insulating oxide to act as a tunneling or as passivation layer material such as $\mathrm{MgO}, \mathrm{Al}_{2} \mathrm{O}_{3} \cdot \mathrm{ZnO}, \mathrm{ZrO}_{2}$, and $\mathrm{Y}_{2} \mathrm{O}_{3}$ [4,5], engineering of the absorber material [6-9], use of buffer layers as recombination barrier [6,7,9], and

${ }^{*}$ Corresponding author. recently use of ultra-thin devices whose charge transport is anticipated to be within solar wavelength $[10,11]$. In this work, we report on light soaking technique as one of the method for improving the conversion efficiency of the eta solar cell and other devices, by prolonged light exposure.

\section{Experimental Details}

\subsection{Sample Preparation}

The solar cells samples were prepared on glass substrates coated with $15 \Omega / v$ sheet resistance $\mathrm{SnO}_{2}: \mathrm{F}$ from Förschungzentrum Jüllich. Different solar cell structures were produced by coating thin films via various techniques with the following procedures being followed for a full solar cell structure of the type $\mathrm{SnO}_{2}: \mathrm{F} / \mathrm{TiO}_{2} /$ $\mathrm{In}(\mathrm{OH})_{x} \mathrm{~S}_{y} / \mathrm{Pb}(\mathrm{OH})_{x} \mathrm{~S}_{y} /$ PEDOT:PSS/Au: A $2 \mu \mathrm{m}$ thick titanium dioxide, $\mathrm{TiO}_{2}$, thin film was coated by sol-gel technique at SgLux $\mathrm{GmbH}$ company using tetra-isopropyl orthotitanate $\left(\mathrm{Ti}\left(\mathrm{C}_{3} \mathrm{H}_{6} \mathrm{OH}\right)_{4}\right)$ mixed with commercial grade solution of isopropanol $\left(\mathrm{CH}_{3} \mathrm{CH}(\mathrm{OH}) \mathrm{CH}_{3}\right)$ as precursors. On top of $\mathrm{TiO}_{2}$, an $80 \mathrm{~nm}$ thick indium hydroxyl sulphide, $\operatorname{In}(\mathrm{OH})_{x} \mathrm{~S}_{y}$, was deposited at $70^{\circ} \mathrm{C}$ for $30 \mathrm{~min}$ utes by chemical bath deposition (CBD) technique using 
aqueous solution containing $\mathrm{InCl}_{3}(0.025 \mathrm{M})$, thioacemide $(0.1 \mathrm{M})$, and $\mathrm{HCl}(0.005 \mathrm{M})$, and repeated 3 times, after every cycle the sample was rinsed in distilled water before the next coating, following procedure as reported by Bayon et al. [6,7,12] and Musembi et al. [12]. the CBD method was also used in depositing $\mathrm{Pb}(\mathrm{OH})_{x} \mathrm{~S}_{y}$ using aqueous solution containing $\mathrm{Pb}\left(\mathrm{CH}_{3} \mathrm{OOH}\right)_{2}(0.05$ $\mathrm{M}), \mathrm{NaOH}(0.2 \mathrm{M})$, triethanolamine $(0.05 \mathrm{M})$, and thiourea $(0.05 \mathrm{M})$ at $40^{\circ} \mathrm{C}$ for 10 minutes using a procedure as reported elsewhere by Gavrilov et al. [13]. The last layer, an undiluted poly $(3,4)$ ethylenedioxythiophe doped with polystyrene sulfonate acid, type Baytron $\mathrm{PH}$ from Bayer $\mathrm{GmbH}$, was then spin coated ontop of $\mathrm{Pb}(\mathrm{OH})_{x} \mathrm{~S}_{y}$. The front and back contacts of the solar cell were coated by resistive vacuum evaporation of Au wire, using a special mask which gave solar cells of $0.126 \mathrm{~cm}^{2}$ areas. The other solar cell structures were realized by eliminating a layer from the complete structure and these included: $\mathrm{SnO}_{2}: \mathrm{F} / \mathrm{In}(\mathrm{OH})_{x} \mathrm{~S}_{y} / \mathrm{Pb}(\mathrm{OH})_{x} \mathrm{~S}_{y} / \mathrm{Au}$,

$\mathrm{SnO}_{2}: \mathrm{F} / \mathrm{In}(\mathrm{OH})_{x} \mathrm{~S}_{y} / \mathrm{Pb}(\mathrm{OH})_{x} \mathrm{~S}_{y} /$ PEDOT:PSS/Au and $\mathrm{SnO}_{2}: \mathrm{F} / \mathrm{TiO}_{2} / \mathrm{In}(\mathrm{OH})_{x} \mathrm{~S}_{y} / \mathrm{Pb}(\mathrm{OH})_{x} \mathrm{~S}_{y} / \mathrm{Au}$.

\subsection{Characterization of the Samples}

The current density-voltage $(\mathrm{J}-\mathrm{U})$ characteristics measurement were performed at room temperature using a DC source meter type Keithley ${ }^{\mathrm{TM}} 237$ high voltage source unit connected to an Hewlett-Packard ${ }^{\mathrm{TM}}$ 34401A multimeter. A halogen lamp from General Electric ${ }^{\mathrm{TM}}(120 \mathrm{~V}$, $300 \mathrm{~W})$ type L268 was used as light source of the calibrated solar simulator (AM 1.5, $100 \mathrm{~mW} / \mathrm{cm}^{2}=1 \mathrm{sun}$ ).

The analysis of soaking effects were done by first taking J-U characteristics of as-prepared solar cell, and then leaving it exposed to the solar simulator light for 180 minutes continuous. During this duration, the soaking effects were being monitored by taking J-U measurements after interval of 20 minutes.

External quantum efficiency measurements were used to study degradation of the solar cell after 180 minutes soaking effects for one of the solar cell structures. The analysis was done for as-prepared solar cell, then after 180 minutes light soaking, subsequently after 24 hours and 96 hours. One week old cell was also analyzed to study soaking effects.

\section{Results and Discussion}

\subsection{J-U Characterization during Soaking}

The performance of $\mathrm{SnO}_{2}: \mathrm{F} / \mathrm{TiO}_{2} / \mathrm{In}(\mathrm{OH})_{x} \mathrm{~S}_{y} / \mathrm{Pb}(\mathrm{OH})_{x} \mathrm{~S}_{y} /$ $\mathrm{Au}$ eta solar cell soaked in solar simulator light for 120 minutes is shown in Figure 1. Its photovoltaic parameters, fill factor $(F F)$, open circuit voltage $\left(U_{o c}\right)$ and efficiency (eff) as a function of light soaking duration in minutes are given. The solar cell showed an exponential increase in conversion efficiency, from eff $=0.13 \%$ for

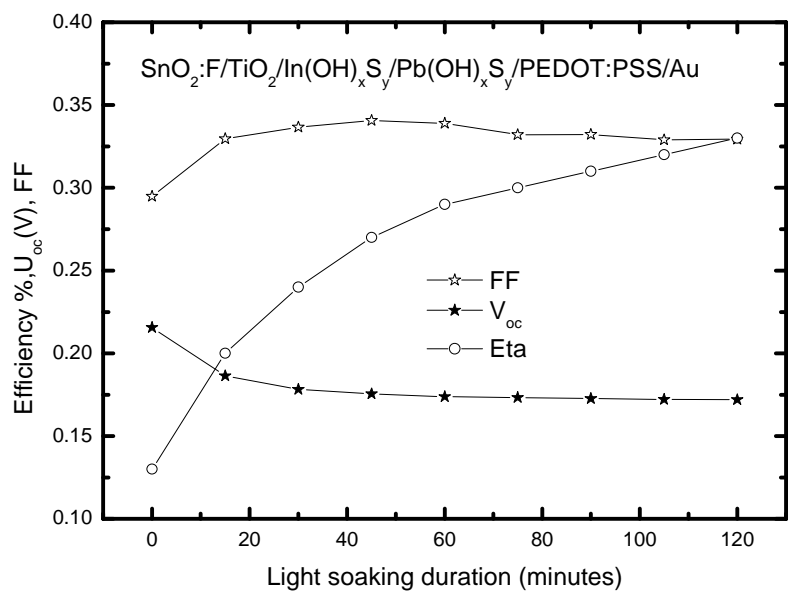

Figure 1. Light soaking characteristics for $\mathrm{SnO}_{2}: \mathrm{F} / \mathrm{TiO}_{2} /$ $\operatorname{In}(\mathrm{OH})_{x} \mathrm{~S}_{y} / \mathrm{Pb}(\mathrm{OH})_{x} \mathrm{~S}_{y} / \mathrm{PEDOT}: \mathrm{PSS} / \mathrm{Au}$ solar cell.

as-prepared solar cell to as high as eff $=0.33 \%$ representing increment factor of 2.5 , while on the other hand, short-circuit current density showed an increment by a factor of 2.8 from $J_{\mathrm{sc}}=2.1 \mathrm{~mA} / \mathrm{cm}^{2}$ to $5.9 \mathrm{~mA} / \mathrm{cm}^{2}$.

The effect of light soaking for similar device but without $\mathrm{TiO}_{2}$ window layer is shown in Figure 2. The $\mathrm{SnO}_{2}: \mathrm{F} / \mathrm{In}(\mathrm{OH})_{x} \mathrm{~S}_{y} / \mathrm{Pb}(\mathrm{OH})_{x} \mathrm{~S}_{y} / \mathrm{PEDOT}: \mathrm{PSS} / \mathrm{Au}$ solar cell device, after soaking for extended duration of $180 \mathrm{~min}-$ utes, the conversion efficiency increased from $0.29 \%$ to $0.78 \%$ representing an increment factor of 2.7 , while short circuit current density reached a maximum value of $J_{\mathrm{sc}}=10.1 \mathrm{~mA} / \mathrm{cm}^{2}$ from a minimum value of $J_{\mathrm{sc}}=3.4$ $\mathrm{mA} / \mathrm{cm}^{2}$ for as-prepared solar cell for the same duration representing an increment factor of about 3. The $U_{o c}$ of this type of device was observed to decrease with soaking duration similar to that of complete eta solar cell shown in Figure 1, while fill factor, there was a slight increment and after 30 minutes of soaking, it started to decrease for the rest of duration the sample was soaked.

The next experiment tested on the effect of light soaking on a reduced type solar cell which has either the polymer material removed or both $\mathrm{TiO}_{2}$ and the polymer material. The fill factor and open circuit voltage of $\mathrm{SnO}_{2}$ : $\mathrm{F} / \mathrm{TiO}_{2} / \mathrm{In}(\mathrm{OH})_{x} \mathrm{~S}_{y} / \mathrm{Pb}(\mathrm{OH})_{x} \mathrm{~S}_{y} / \mathrm{Au}$ solar cell both showed a decrement of between 0.01 and 0.03 respectively, as shown in Figure 3. The short circuit current density, $J_{\text {sc }}$ and conversion efficiency, (eff) both increased by a factor of about 2.1 and 1.6 respectively after soaking the solar cell for 180 minutes. The initial value was $J_{\mathrm{sc}}=4.7$ $\mathrm{mA} / \mathrm{cm}^{2}$ for as-prepared solar cell and increased to $J_{\mathrm{sc}}=$ $9.9 \mathrm{~mA} / \mathrm{cm}^{2}$ after light soaking, while the conversion efficiency reached $0.56 \%$ from the initial value of $0.36 \%$.

Lastly, the solar cell device to be studied was the simplest p-n heterostructure consisting of $\mathrm{SnO}_{2}: \mathrm{F} / \mathrm{In}(\mathrm{OH})_{\mathrm{x}} \mathrm{S}_{\mathrm{y}} /$ $\mathrm{Pb}(\mathrm{OH})_{\mathrm{x}} \mathrm{S}_{\mathrm{y}} / \mathrm{Au}$, this is shown in Figure 4.

For this type of device in Figure 4, the open circuit voltage and fill factor behaviour was similar to that 


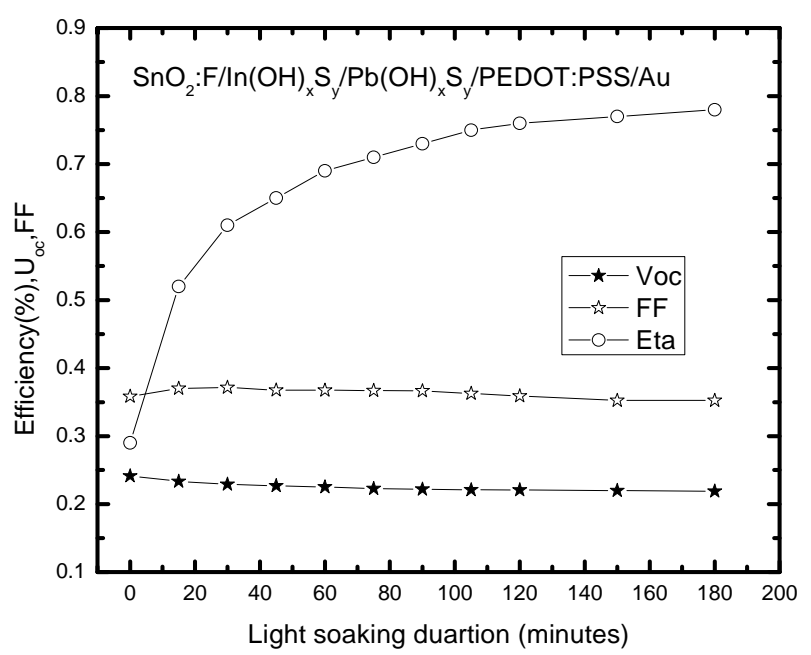

Figure 2. Light soaking characteristics for $\mathrm{SnO}_{2}: \mathrm{F} / \mathrm{In}(\mathrm{OH})_{x} \mathrm{~S}_{y} /$ PEDOT:PSS/Au solar cell.

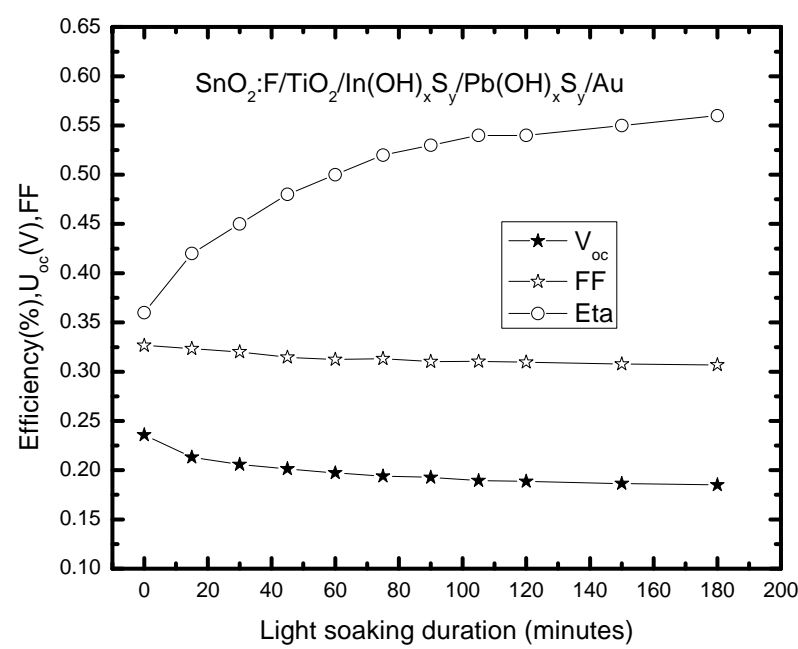

Figure 3. Light soaking characteristics for $\mathrm{SnO}_{2}: \mathrm{F} / \mathrm{TiO}_{2} /$ $\operatorname{In}(\mathrm{OH})_{x} \mathrm{~S}_{y} / \mathrm{Pb}(\mathrm{OH})_{x} \mathrm{~S}_{y} / \mathrm{Au}$ solar cell.

displayed by the sample given in Figure 3. That is, there was a general decrease with increasing light soaking duration. On the other hand, conversion efficiency and short circuit-current density changed by a factor of about 2.0 and 2.5 respectively. The final value of $J_{\mathrm{sc}}=14.3$ $\mathrm{mA} / \mathrm{cm}^{2}$ after light soaking for 180 minutes from an initial value of about $J_{\mathrm{sc}}=5.7 \mathrm{~mA} / \mathrm{cm}^{2}$, while the conversion efficiency, the value for as-prepared solar cell was $0.60 \%$ and increased up to $1.19 \%$ after light soaking for 180 minutes.

From the preliminary results of light soaking experiments for full eta solar cell with buffer layer and simplified solar cell devices realized by eliminating some layers, it can be deduce that light soaking improves the solar cell overall conversion efficiency and short circuit current density. The parameters have been observed to improve with light soaking duration since after 180 minutes

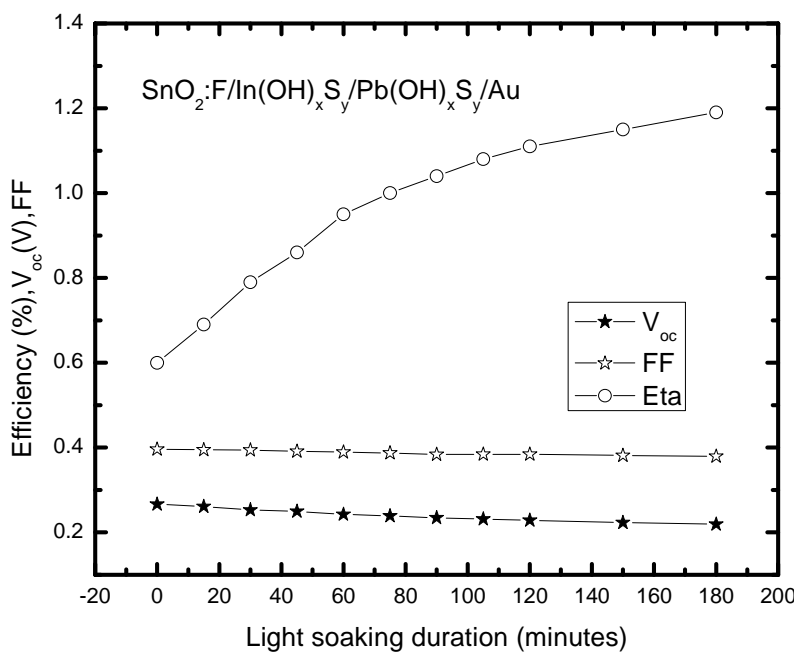

Figure 4. Light soaking characteristics for $\mathrm{SnO}_{2}: \mathrm{F} / \mathrm{In}(\mathrm{OH})_{x} \mathrm{~S}_{y} /$ $\mathrm{Pb}(\mathrm{OH})_{x} \mathrm{~S}_{y} / \mathrm{Au}$ solar cell.

of samples exposure to solar simulator light, both efficiency and short circuit current density increased by a factor of between $\sim 2$ and 3 which is a very big change given the initial values of as-prepared solar cells. Clearly, it can be observed that all samples containing PEDOT: PSS as a hole conductor had the highest gain in overall conversion efficiency of the solar cell, compare devices A $\left(\mathrm{SnO}_{2}: \mathrm{F} / \mathrm{TiO}_{2} / \mathrm{In}(\mathrm{OH})_{x} \mathrm{~S}_{y} / \mathrm{Pb}(\mathrm{OH})_{x} \mathrm{~S}_{y} / \mathrm{PEDOT}\right.$ :PSS/Au $)$ and $\mathbf{C}\left(\mathrm{SnO}_{2}: \mathrm{F} / \mathrm{TiO}_{2} / \mathrm{In}(\mathrm{OH})_{x} \mathrm{~S}_{y} / \mathrm{Pb}(\mathrm{OH})_{x} \mathrm{~S}_{y} / \mathrm{Au}\right.$ in Table 1 against devices $\mathbf{B}\left(\mathrm{SnO}_{2}: \mathrm{F} /(\mathrm{OH})_{x} \mathrm{~S}_{y} / \mathrm{Pb}(\mathrm{OH})_{x} \mathrm{~S}_{y} / \mathrm{PEDOT}\right.$ : $\mathrm{PSS} / \mathrm{Au})$ and $\mathbf{D}\left(\mathrm{SnO}_{2}: \mathrm{F} / \mathrm{In}(\mathrm{OH})_{\mathrm{x}} \mathrm{S}_{\mathrm{y}} / \mathrm{Pb}(\mathrm{OH})_{\mathrm{x}} \mathrm{S}_{\mathrm{y}} / \mathrm{Au}\right)$.

Another interesting observation is that, when $\mathrm{TiO}_{2}$ layer is removed for samples of similar structure, that is devices containing PEDOT:PSS layer and those without, as shown by pairs of samples $\mathbf{A}, \mathbf{C}$ and $\mathbf{B}, \mathbf{D}$; the absence of $\mathrm{TiO}_{2}$ layer in both cases results into increment of short circuit current density and therefore the overall conversion efficiency. This shows that PEDOT:PSS acts as a protective layer to the $\mathrm{Pb}(\mathrm{OH})_{x} \mathrm{~S}_{y}$ and prevents Au back contact from diffusing into the bulk of the material thus increasing surface states leading to higher recombination rate. On the other hand, although $\mathrm{TiO}_{2}$ improves the optoelectrical properties of the respective solar cell because of its highly structured porous surface, its presence together with the $\operatorname{In}(\mathrm{OH})_{x} \mathrm{~S}_{y}$ layer material, tends to increase the space charge region such that recombination loss can set in, but when $\mathrm{TiO}_{2}$ is absent the distant of the charge travels is shorter and thus resulting to higher short circuit-current density and conversion efficiency as a result for as-prepared sample. On the other hand, the increment in conversion efficiency of the solar cells can be attributed to the filling of trap states hence resulting to less recombination losses and this translates to higher conversion short circuit current density and conversion efficiency as the sample is soaked under illumination. 
Table 1. Changes in solar cell parameters of eta solar cell and that of simplified devices, $d$ represents decrease in value, $i-d$ represents increase then decrease in value.

\begin{tabular}{ccccc}
\hline device PV & $J_{\text {sc }}$ & $V_{\text {oc }}$ & FF & Eff \\
\hline A & 2.8 & d & i-d & 2.5 \\
B & 2.1 & d & d & 1.6 \\
C & 3.0 & d & i-d & 2.7 \\
D & 2.5 & d & d & 2.0 \\
\hline
\end{tabular}

\subsection{Degradation Studies after Light Soaking}

Degradation studies after soaking was performed for a device of similar structure to solar cell device $\mathbf{C}$ shown in Table 1. The external quantum efficiency first was measured before light soaking and found to be about $17 \%$ at peak wavelength of about $\lambda=505 \mathrm{~nm}$ for asprepared sample, this is as shown in Figure 5. Then the sample was exposed to solar simulator light for $180 \mathrm{~min}-$ utes ( 3 hours), the external quantum efficiency was again measured and found to have increased to $25 \%$ at peak wavelength of about $\lambda=514 \mathrm{~nm}$.

Henceforth, the sample was kept in inert gas filled chamber, and subsequent measurement were taken after 24 hours and 96 hours and found external quantum efficiency to have dropped to $23 \%$ (at peak wavelength of about $\lambda=513 \mathrm{~nm}$ ) and $21 \%$ (at peak wavelength of about $\lambda=510 \mathrm{~nm}$ ) respectively. The drop in external quantum efficiency after soaking can be attributed to charge-discharge effects of the deep levels present in $\mathrm{In}(\mathrm{OH})_{x} \mathrm{~S}_{y}$ layer as reported elsewhere in the literature $[9,13]$. The samples have also been found to be resilient to light soaking (figure not shown), 1 week old sample was found to regain both short circuit current density and conversion efficiency by a factor of about 1.3 and 1.2 respectively.

\section{Conclusion}

Light soaking has been performed for the first time in eta solar cell device. The effects of light soaking on eta solar cell with the following layers:

$\mathrm{SnO}_{2}: \mathrm{F} / \mathrm{TiO}_{2} / \mathrm{In}(\mathrm{OH})_{x} \mathrm{~S}_{y} / \mathrm{Pb}(\mathrm{OH})_{x} \mathrm{~S}_{y} / \mathrm{PEDOT}: \mathrm{PSS} / \mathrm{Au}$ and other reduced devices derived from this structure, have been investigated. It has been found that conversion efficiency and short circuit current density can be increased by light soaking in solar cell devices having $\operatorname{In}(\mathrm{OH})_{x} \mathrm{~S}_{y} /$ $\mathrm{Pb}(\mathrm{OH})_{x} \mathrm{~S}_{y}$ heterostructure. The increase in efficiency and short circuit current density has been attributed to the filling of trap states and/or charge-discharge of deep levels in $\mathrm{In}(\mathrm{OH})_{x} \mathrm{~S}_{y}$. The question about the specific layer/s or interface responsible for the observed light soaking effects is still not completely clear and therefore necessitates further investigation.

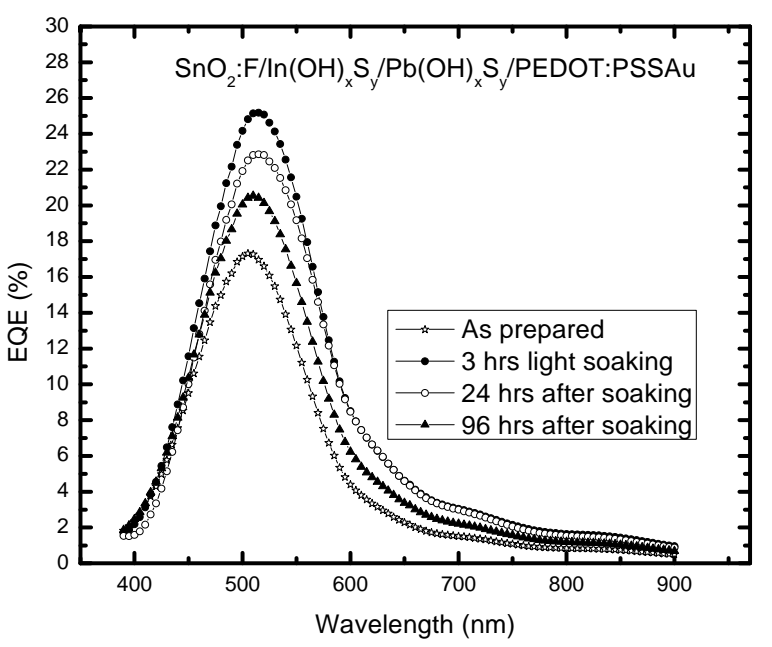

Figure 5. Degradation studies using external quantum quantum efficiency for $\mathrm{SnO}_{2}: \mathrm{F} / \mathrm{In}(\mathrm{OH})_{x} \mathrm{~S}_{y} / \mathrm{Pb}(\mathrm{OH})_{x} \mathrm{~S}_{y} / \mathrm{PEDOT}$ : PSS/Au solar cell.

\section{Acknowledgements}

R. J. M wish to thank the organic solar cells group headed by Konstantinos Fostiropoulous hosting him and for financial support through Hermholtz-Zentrum Berlin für Materialien und Energie. Gratefully thanked also are the University of Nairobi (UoN), DAAD, and International Programmes in Physical Sciences (IPPS), Uppsala University for financial support.

\section{REFERENCES}

[1] S. Siebentritt, K. Ernst, C. H. Fischer, R. Koenenkamp and M. Ch. Lux-Steiner, "CdTe and CdS as Extremely Thin Absorber Material in an eta Solar Cell," Proc. 14th Eur. Photovoltaic Solar Energy Conf. Exhibition. Barcelona, Spain, 1997, p. 1823.

[2] I. Kaiser, K. Ernst, C. H. Fischer, R. Koenenkamp, C. Rost, I. Sieber and M. Ch. Lux-Steiner, "The eta Solar Cell with $\mathrm{CuInS}_{2}$ : A Photovoltaic Cell Concept Using an Extremely Thin Absorber," Solar Energy Materials and Solar Cells, Vol. 67, No. 1-4, 2001, pp. 89-96. http://dx.doi.org/10.1016/S0927-0248(00)00267-1

[3] B. O'Regan and M. Graetzel, “A Low Cost High Efficiency Solar Cell Based on Dye-Sensitized Colloidal $\mathrm{TiO}_{2}$ Films," Nature, Vol. 353, No. 6346, 1991, pp. 737 740. http://dx.doi.org/10.1038/353737a0

[4] T. P. Brennan, O. T. Katherine, E. Roelofs, J. Xu, F. B. Prinz and S. F. Bent, "Efficiency Enhancement of Solid State PbS Quantum Dot-Sensitized Solar Cells with $\mathrm{Al}_{2} \mathrm{O}_{3}$ Barrier Layer," Journal of Material Chemistry A, Vol. 1, No. 26, 2013, pp. 7566-7571. http://dx.doi.org/10.1039/c3ta10903h

[5] C. Grasso and M. Burgelman, "Theoretical Study on the Effect of an Intermediate Layer in CIS Based ETA Solar Cells," Thin Solid Films, Vol. 451-452, 2004, pp. 156159.

[6] R. Bayon, R. Musembi, A. Belaidi, M. Bar, T. Gu- 
miskaya, C. H. Fischer, M. Ch. Lux-Steiner and Th. Dittrich, "Highly Structured $\mathrm{TiO}_{2} / \mathrm{In}(\mathrm{OH})_{\mathrm{x}} \mathrm{S}_{\mathrm{y}} / \mathrm{PbS} / \mathrm{PEDOT}$ : PSS for Photovoltaic Applications," Solar Energy Materials and Solar Cells, Vol. 89, No. 1, 2005, pp. 13-25. http://dx.doi.org/10.1016/i.solmat.2004.11.011

[7] R. Bayon, R. Musembi, A. Belaidi, M. Bar, T. Gumiskaya, C. H. Fischer, M. Ch. Lux-Steiner and Th. Dittrich, "Highly Structured $\mathrm{TiO}_{2} / \mathrm{In}(\mathrm{OH})_{\mathrm{x}} \mathrm{S}_{\mathrm{y}} / \mathrm{PbS} / \mathrm{PEDOT}$ :PSS to be used in Photovoltaic Applications," Comptes Rendus Chimie, Vol. 9, No. 5, 2006, pp. 730-734. http://dx.doi.org/10.1016/j.crci.2005.02.049

[8] E. Karber, A. Abass, S. Khelifi, M. Burgelman, A. Katerski and M. Krunks, "Electrical Characterization of AllLayer Sprayed Solar Cells Based on ZnO Nanorods and Extremely Thin CIS Absorber," Solar Energy, Vol. 91, 2013, pp. 48-58.

http://dx.doi.org/10.1016/j.solener.2013.01.020

[9] A. Belaidi, R. Bayon, L. Dloczik, K. Ernst, M. Ch. LuxSteiner and R. Konenkamp, "Comparison of Different Thin Films Absorbers Used in eta Solar Cells," Thin Solid Films, Vol. 431-432, 2003, pp. 488-491.

[10] S. Gavrilov, I. Oja, B. Lim, A. Belaidi, W. Bohne, E.
Strub, J. Roahrich, M. Ch. Lux-Steiner and Th. Dittrich, "Charge Selective Contact on Ultra-Thin $\mathrm{In}(\mathrm{OH})_{\mathrm{x}} \mathrm{S}_{\mathrm{y}}$ Heterostructure Prepared by SILAR," Physica Status Solidi (a), Vol. 203, No. 5, 2006, pp. 1024-1029. http://dx.doi.org/10.1002/pssa.200521468

[11] I. Oja, A. Belaidi, L. Dloczik, M. Ch. Lux-Steiner and Th. Dittrich, "Photoelectrochemical Properties of $\operatorname{In}(\mathrm{OH})_{\mathrm{x}} \mathrm{S}_{\mathrm{y}} /$ $\mathrm{PbS}(\mathrm{O})$ Structures Deposited by SILAR on $\mathrm{TiO}_{2}$," Semiconductor Science and Technology, Vol. 21, No. 4, 2006, pp. 520-526. http://dx.doi.org/10.1088/0268-1242/21/4/018

[12] R. J. Musembi, M. Rusu, J. M. Mwabora, B. O. Aduda, K. Fostiropoulos and M. Ch. Lux-Steiner, "Intensity and Temperature Characterization of eta Solar Cell," Physica Status Solidi (a), Vol. 205, No. 7, 2008, pp. 1713-1718. http://dx.doi.org/10.1002/pssa.200723466

[13] F. Lenzmann, M. Nanu, O. Kijatkina and A. Belaidi, "Substancial Improvement of the Photovoltaic Characteristics of $\mathrm{TiO}_{2} / \mathrm{CuInS}_{2}$ Interfaces by the Use of Recombination Barrier Coatings," Thin Solid Films, Vol. 451-452, 2004, pp. 639-643. 